\title{
Kabuki syndrome: from Japanese theater to Poland - a case report
}

\section{Zespót Kabuki: z japońskiego teatru do Polski - opis przypadku}

\author{
Bartosz Kępka1 (D), Katarzyna Marzęda' (D), Magdalena Chrościńska-Krawczyk² (iD) \\ ${ }^{1}$ Studenckie Koło Naukowe przy Klinice Neurologii Dziecięcej III Katedry Pediatrii, Uniwersytet Medyczny w Lublinie \\ ${ }^{2}$ Klinika Neurologii Dziecięcej III Katedry Pediatrii, Uniwersytet Medyczny w Lublinie
}

DOI:10.20966/chn.2019.56.443

\section{STRESZCZENIE}

Zespół Kabuki (zespół Niikawa-Kuroki) jest to rzadka choroba obejmująca zespót wad wrodzonych, często połączonych z niepełnosprawnością intelektualną. Opisany po raz pierwszy u dziesięciorga pacjentów przez Niikawę i Kurokiego w 1981 r. Kiedyś uznawany za charakterystyczny dla obszaru Japonii, obecnie przypadki zespołu opisywane są na całym świecie, jednakże brak dokładnych informacji na temat częstości występowania. Nazwa pochodzi od tradycyjnego japońskiego teatru, którego aktorzy nosili charakterystyczny makijaż podobny do cech fenotypowych twarzy pacjentów. W pracy opisano przypadek 6-letniej dziewczynki, urodzonej z cechami hipotrofii wewnątrzmacicznej, rozszczepem podniebienia, małogłowiem, klinodaktylią palców V rąk, cofniętą żuchwą, nisko osadzonymi uszami i zniekształceniem klatki piersiowej. Mimo licznych specjalistycznych konsultacji, ostateczne rozpoznanie postawiono dopiero 15 miesięcy po urodzeniu, co podkreśla trudności związane z rozpoznaniem rzadkich chorób. Jednocześnie przypadek opisywanej Pacjentki pokazuje jak odrębne mogą być objawy u chorych z rozpoznanym zespotem Kabuki. Przeprowadzone niedawno badania rzucity nowe światto na możliwą etiologię choroby (mutacja genu KMT2D lub $K D M 6 A$ ) i jednocześnie zmusity do próby opracowania nowych kryteriów rozpoznania zespołu. Opisany przypadek, a także doniesienia z literatury potwierdzają jednak, że potrzebne są kolejne badania nad tym rzadkim schorzeniem.

Słowa kluczowe: zespół Kabuki, dysmorfia twarzy, upośledzenie umystowe, hipotonia, rozszczep podniebienia, mutacja genu KMT2D, mutacja genu KDM6A

\section{ABSTRACT}

Kabuki syndrome is a rare disease manifested by several congenital anomalies, often connected with intellectual disability. The syndrome was first described by Niikawa and Kuroki in 1981. It was considered typical of Japan, however nowadays new cases are reported all over the world. Unfortunately, there is no precise epidemiological data. The name of syndrome derives from traditional Japanese theater where actors used to wear characteristic makeup, resembling patients' phenotypic facial features. We report on a case of a 6 -year-old girl born with intrauterine growth restriction (IUGR), cleft palate, microcephaly, clinodactyly of $5^{\text {th }}$ fingers, micrognathism, low set ears, chest malformation. Despite numerous consultations, the final diagnosis was not made until $15^{\text {th }}$ month of age, which underlines difficulties in diagnosing rare diseases. This case discusses a wide spectrum of symptoms of Kabuki syndrome in a 6-year-old girl. Recent research has shed a new light on the disease's etiology (mutation in KMT2D or KDM6A gene) and led to establishing new diagnostic criteria. However, the described case and literature reports confirm that more research is needed into this rare disease.

Keywords: Kabuki syndrome, face abnormalities, intellectual disability, hypotonia, cleft palate, KMT2D mutation, KDM6A mutation

\section{INTRODUCTION}

Kabuki syndrome (also known as Kabuki make-up syndrome - KMS, Niikawa-Kuroki syndrome) is a rare, congenital, genetically based disease. It was reported for the first time by Japanese physicians Niikawa and Kuroki in 1981. Prevalence in Japanese population is estimated to be 1: $32000-86000$ births. Exact prevalence in Caucasians is unknown. The name of the disease refers to the traditional Japanese theater, where actors used to wear characteristic makeup, resembling patients' phenotypic facial features. The name variant 'Kabuki makeup syndrome' is not recommended due to the pejorative connotation and potential patient's stigmatization [1-3].

The diagnosis of Kabuki syndrome used to be based on five cardinal features: facial abnormalities $(100 \%)$, mild to moderate intellectual disability (84\%), postnatal growth restriction (55\%), skeletal anomalies $(88 \%)$ with joints hy- permobility (74\%), and dermatoglyphic abnormalities in the form of persistent fetal pads (93\%) [2-4].

The most prominent neurological symptoms include mild to moderate intellectual disability, seizures, microcephaly, hypotonia. Patients with concomitant autism spectrum disorders (ASD) or stereotypic and repetitive movements are also reported, as well as those with hearing loss. Most sufferers are able to communicate verbally and are able to take advantage of education in public schools or educational institutions for people with moderate disabilities [4].

Typically, clinical findings are facial abnormalities in almost $100 \%$ patients, i.e. everted lower eyelid, arched or broad, sparse or notched at one-third eyebrows, long palpebral fissures with long eyelashes, flat nasal tip, short columnella, large, prominent ears. More rarely occurs strabismus, blue sclera, cleft palate or lip, preauricular pits or fissures and abnormal dentition [2-4]. 
The most common skeletal anomalies include brachydactyly $\mathrm{V}$, fifth digit clinodactyly, various types of scoliosis and/or kyphosis, malformed vertebrae, sagittal cleft vertebra, spina bifida occulta, costal anomalies, hip dislocation, and joints hypermobility. Current research focuses on causes of skeletal anomalies, whether they are neurogenic or related to changes in the loose connective tissue $[3,4]$.

Other symptoms of Kabuki syndrome are congenital defects of the heart and its electrical conducting system, such as ventrical septum defect, atrial septum defect, tetralogy of Fallot, coarctation or aneurysm of the aorta, patent ductus arteriosus, transposition of great arteries, and right bundle branch block $[3,4]$.

Kabuki syndrome is caused by mutation in KMT2D (a.k.a. MLL2) or KDM6A gene. The former is observed in $55-80 \%$ cases and refers to defect in lysine methyltransferase $2 \mathrm{D}$ synthesis, the latter mutation is less frequent seen in $2-6 \%$ cases. KDM6A gene is responsible for lysine-specific demethylase $6 \mathrm{~A}$ synthesis. Both genes control histone methylation and thus the activation of relevant genes during body development. Most of mutations occur de novo, but family occurrence in the autosomal dominant mechanism is also described. The gene penetration seems to be complete, but there is no exact data [4-7].

Mutation variant affects clinical features and their severity. Patients with KMT2D mutation more often develop kidney dysfunctions, joints dislocations, palate anomalies, and premature thelarche. Those with KDM6A mutation are more often affected by hypoglycemia due to hyperinsulinism, as well as excessive hair growth, large incisors, long toes [4].

\section{CASE REPORT}

The patient, a 6-year-old girl born by Caesarean section in 38 th week of pregnancy with signs of intrauterine growth restriction, mother's first pregnancy, weight $2460 \mathrm{~g}$, height $54 \mathrm{~cm}$, head circumference $30 \mathrm{~cm}$, chest circumference $31 \mathrm{~cm}$, with an Apgar score of 7 in the first minute, then 8 , 8 and 9 in 3, 5, and 10 minute respectively. She was transferred to the Neonatal Pathology Ward due to suspected intrauterine infection.

The course of the pregnancy was uneventful apart from nausea, emesis and hypersensitivity to smell reported by the mother at the beginning of the first trimester which continued till the term of labor. The mother was prescribed a small dose of Hydroxyzine continued for 3-4 months to relieve emesis and anxiety.

On prenatal USG examination considerable nuchal translucency was found and suggestion of hydrocephalus was made. It was decided to conduct invasive prenatal testing. Amniocentesis (performed twice) demonstrated normal karyotype without any chromosomal abnormalities (46, XX). Due to mother's uterine fibroids, the pregnancy was terminated by C-section. The mother's past history revealed fibroids about 10 years ago, however they went untreated. During the labor, the amniotic fluid was green. The oligohydramnios suspected after the first USG was confirmed.

Family medical history found no congenital defects, genetically pretermined diseases, or intellectual disability.
Both parents are healthy, the mother does not take any medication.

During hospitalization at the Neonatal Pathology Ward, the girl's general condition was quite good. The physical examination found generalized hypotonia and signs of dysmorphia, i.e. cleft palate, microcephaly, clinodactyly of $5^{\text {th }}$ fingers, micrognathism, low set ears, chest malformation. In addition to that, xantodermia was observed. Auscultation revealed no abnormal sounds, heart rate 160 min., physiological vesicular murmur, the liver and spleen were not enlarged. Laboratory tests showed increased infection parameters, thrombocytopenia, increased levels of conjugated and unconjugated bilirubin, and hypoglycaemia. X-rays taken at that time showed increased pulmonary vascular pattern on both sides, without any pulmonary infiltrates. Ultrasonography detected no enlargement of the abdominal organs, the kidneys were abnormally elongated without any focal lesions, which required further monitoring. Two weeks after birth the transfontanelle ultrasound was performed which confirmed no focal lesions, no ventricular enlargement (the lateral ventricle $18 \mathrm{~mm}$, cranial width $81 \mathrm{~mm}$ ), the choroid plexuses without any abnormalities, no dilated pericerebral areas. Due to the discovered aberrations, the suspicion of Pierre Robin's sequence was made, and the blood was cytogenetically tested for 22q11 microdeletion. The patient's condition was consulted with other specialists (surgeon, orthopedist, ophthalmologist, geneticist). During the stay in the Neonatal Pathology Ward the patient presented with troubled eating and was not gaining weight. Therefore, the parenteral feeding was implemented. The mother was recommended follow-up consultations with geneticist, surgeon, orthopedist, cardiologist, neurologist, ophthalmologist, and general practitioner. During the first months after birth, the patient was often suffering from the urinary tract infection caused by Escherichia Coli, but additional testing showed no pathology.

Initially, due to the cleft palate and dysmorphic facial abnormalities (Fig 1., Fig 2.) Pierre Robin's sequence was suspected. Cytogenetic testing done by MLPA method showed no signs of 22q11 microdeletion typical for this syndrome. The patient was operated on for cleft palate, which was performed 8 months after birth.

The definitive diagnosis of Kabuki syndrome was made 15 months after birth. Molecular testing showed Q3934X mutation in one allele of MLL2 (KMT2D) gene. Although that mutation was not included in the Human Gene Mutation Database (HGMD), basing on the nature of detected change it was deduced that Q3934X mutation is in fact pathogenic. In addition, Q3932E mutation was also discovered. Lack of information about this particular mutation in the medical literature does not allow to ultimately decide whether or not this is a pathogenic change. Eventually, Q3932E mutation was not brought out in the results of genotype testing.

Patient's further development was monitored by specialists. When the girl was 3 months old the pediatric neurologist examined her and found minor problems with swallowing related to the cleft palate, micrognathism and collapsed tongue, hypotonia, tendon reflexes were nor- 


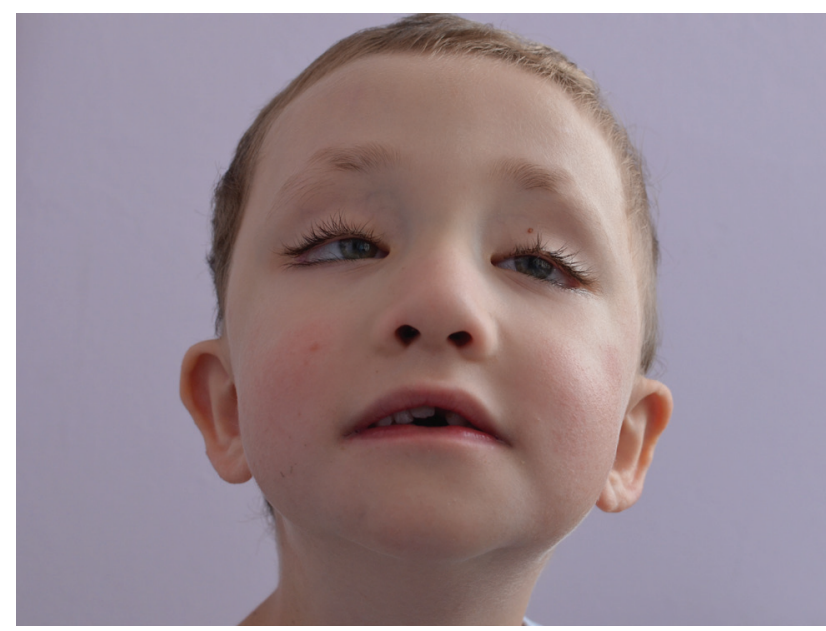

Fig. 1. A 6-year-old patient showing facial dysmorphic features typical of Kabuki syndrome.

Ryc. 1. Sześcioletnia pacjentka prezentująca zmiany dysmorficzne twarzy typowe dla zespołu Kabuki.

mal. At the age of 6 months the patient started to roll over, she was able to grab toys, move around on the floor, keep the head in the axis of her body, and was sitting with support. After 9 months she was able to sit by herself but was not able to stand up or crawl. Hypotonia was still observed, but the reflexes remained normal. The patient was rehabilitated for hypotonia, which is continued. According to the patient's mother, she started to walk with support around 10 months of age and was making her first independent steps around 15 months. The parents described her gait as very unstable, broad-based. During the next consultation with the pediatric neurologist at the age of 2, there was marked hypotonia and delay in the development of speech and cognition was noted. Therefore, it was decided to take MRI of the brain. MRI was carried out under general anesthesia. The scan revealed diffuse focal lesions located symmetrically in the periventricular white matter of the frontoparietal area (possibly demyelinating), and signs of the corpus callosum hypoplasia. The parents reported several incidents of spasms which appeared mostly during patient's rest and before sleep. Moreover, sucking reflex which was accompanied by hair pulling was the reason to order EEG. Unfortunately, the test was not completed as the patient pulled off the electrodes due to her hypersensitive head skin. Another EEG, this time during sleep, showed no pathological changes. Her parents reported that after using special finger cover, the episodes of hair pulling disappeared. According to her mother, the girl said her first words when around 3 years old. After the cleft palate surgery, which was performed 8 months after birth, the problem of narrow palate developed, so the patient remained under professional laryngological follow-up. At the age of 4, the girl was given 3 sessions of electrostimulation of the palate, which brought significant improvement of speech. At this moment her speech is still mumbled. At that time the patient started attending integrated preschool, where she participated in many developmental activities. The patient was

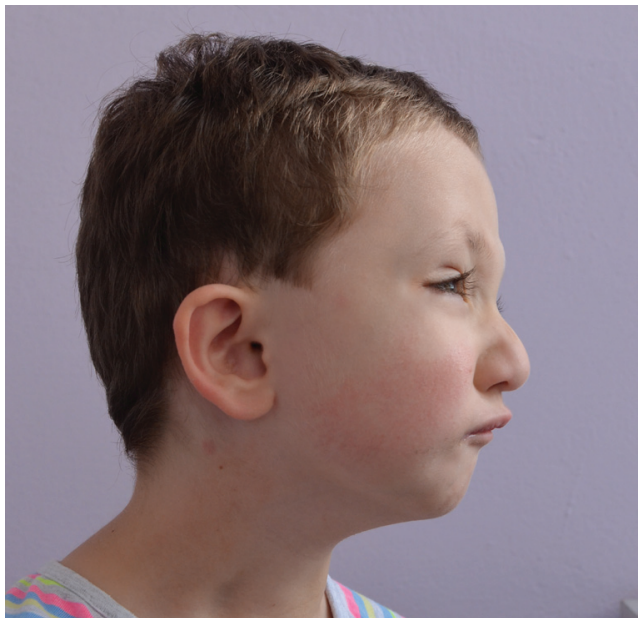

Fig. 2. Profile view of the same patient. Ryc. 2. Profil twarzy tej samej pacjentki.

consulted by a psychologist. The results revealed delayed intellectual development by 1.5 year compared to other children in her age. The patient's mother describes her as very active, lively, without any problems with peers, although she mentions problems with concentration, confusion and inadequacy in asking questions.

Since the age of 9 months the patient has been rehabilitated regularly. Due to feet valgus and hip abduction diagnosed by orthopedist, she was recommended to wear special insoles and exercises. Because of weakened chest and nape muscles, the patient was also recommended special exercises to prevent hunching. Ophthalmologic consultation performed after birth excluded any sight problems. Unfortunately, the parents noticed problems with vision when the girl was around 3 years old. The diagnosis of strabismus was made and the patient was prescribed glasses. Dilated foramen ovale with insignificant leakage from left to right, that was discovered shortly after birth requires additional testing. ECHO of the heart revealed tricuspid insufficiency $\mathrm{I}^{\circ}$ (tricuspid valve regurgitation $2 \mathrm{~m} / \mathrm{s}$ ).

The patient's parents also reported recurrent episodes of otitis and bronchitis which prevented the girl's attending the preschool. The endoscopy of the nasal passages was performed and it found narrow posterior nostrils, small pharyngeal tonsil, the anatomical structure of the larynx appeared normal. Laryngological examination has confirmed hypertelorism, wide base of the nose, and elongated eyelids. Additionally, sensitivity test was performed which confirmed allergy to egg whites, dust mites, and grass pollen.

At present, the patient is on no medication apart from regular supplementation of vitamin D3.

\section{DISCUSSION}

Correct and early diagnosis of rare diseases poses a diagnostic challenge. Kabuki syndrome seems to be often misdiagnosed, so the exact prevalence is unknown. $[1,2]$. At the 
Tab. I. The presence of clinical features in patient organized according to the new diagnostic criteria. Adapted from Makrythanasis P. et al. [7]

Tab. I. Obecność cech klinicznych u pacjentki uporządkowanych według nowych kryteriów diagnostycznych. Zaadaptowana na podstawie Makrythanasis P. et al. [7]

\begin{tabular}{l|c|c}
\hline \multicolumn{1}{c|}{ Clinical feature } & $\begin{array}{c}\text { Presence } \\
\text { in patient }\end{array}$ & Points given \\
\hline Facial abnormalities & & 4 (for 5 possible) \\
\hline Long palpebral fissures & + & \\
\hline $\begin{array}{l}\text { Arched eyebrows, } \\
\text { sparsed in lateral one- } \\
\text { third }\end{array}$ & + & \\
\hline Blue sclera & & \\
\hline Everted lower eyelid & - & \\
\hline Ptosis & - & \\
\hline Strabismus & + & \\
\hline Broad nasal root & + & \\
\hline Flat nasal tip & + & \\
\hline Cleft or high palate & + & \\
\hline Large, dysplastic ears & + & \\
\hline Dental failures & + & \\
\hline Oligodontia & - & \\
\hline Micrognathia & + & \\
\hline Thin upper lip and full & + & \\
\hline lower lip & + & \\
\hline Lip nodules & - & \\
\hline Externity abnormalities & & \\
\hline Brachy- or clinodactyly & + & \\
\hline Hip dislocation & - & \\
\hline Lax joints & + & \\
\hline Persistent fetal pads & + & \\
\hline Heart abnormalities & + & \\
\hline Kidney abnormalities & - & \\
\hline Shicrocephaly & & \\
\hline
\end{tabular}

beginning it was thought to be exclusive for Japanese population [1], with morbidity estimated as 1:32 000 [3]. Currently, new cases are reported from all over the world, but exact epidemiology is still undefined. [1,2]

Initially, diagnostic criteria of Kabuki syndrome included five cardinal features, i.e. facial dysmorphy, mild to moderate intellectual disability, postnatal growth restriction, skeletal anomalies with joints hypermobility, and dermatoglyphic abnormalities. Makrythanasis et al. [7] proposed a 10-point phenotypic scoring system. It is also worth mentioning that patients with KMT2D mutation score more points (6.1) compared to those without mutation (4.5). Kabuki syndrome may be caused also by KDM6A mutation, which presents slightly different phe- notype. Because of that, the proposed system was not accepted as diagnostic criteria.

Makrythanasis et al. [7] distinguished 15 facial features with a possible score of $0-5$ points. Other points can be given for skeletal abnormalities, heart or kidney defects, microcephaly, and short stature (one for each feature). The patient must have at least 2 out of 4 diagnosed skeletal malformations to be ascribed a point. Based on these criteria, our patient scored 7 out of 10 points. (Tab. I)

The expert consensus on new criteria for diagnosis was published in 2019 [4]. It has been proposed that Kabuki syndrome can be diagnosed in a patient of any age with a history of hypotension, delayed mental development and/or mental disability, and one or both of the following criteria:

1. KMT2D or KDM6A gene mutation

2. typical phenotypic features: long palpebral fissures with everted one-third lower eyelid and at least two of listed below:

a. arched or broad eyebrows sparse or notched one-third

b. short columnella with depressed nasal tip

c. large protruding or cupped ears

d. persistent fetal pads

All phenotypic features and the presence of KMT2D gene mutation make the diagnosis of Kabuki syndrome highly probable.

As the disease is very rare, there is still lack of knowledge about brain abnormalities in Kabuki syndrome. Several authors reported possible changes in the brainstem and cerebellum [8], bilateral polymicrogyria in the perisylvian region [9], or bilateral polymicrogyria in the occipital lobe [10]. Also mild enlargement of the cerebral ventricles is frequently reported $[3,8]$.

Boisgontier et al. [11] published a paper analyzing brain abnormalities in 6 patients diagnosed with Kabuki syndrome. The study revealed decreased gray matter in the precentral gyrus and middle frontal gyrus. In these areas rest cerebral blood flow was also decreased. The volume of both hippocampi and both dental gyri was significantly lower than in healthy controls. More studies are needed to understand the importance of neuroimaging findings in patients suffering from Kabuki syndrome.

The presented case is another proof that the diagnosis of rare illnesses is often challenging. Widespread knowledge of rare diseases among physicians will help them to recognize the problem and implement early treatment. However, still more research is needed to understand Kabuki syndrome.

\section{REFERENCES}

[1] Cheon C.K., Ko J.M.: Kabuki syndrome: clinical and molecular characteristics. Korean J Pediatr. 2015; 58: 317-324.

[2] Adam M.P., Hudgins L.: Kabuki syndrome: a review. Clin Genet 2005; 67: 209-219.

[3] Niikawa N., Kuroki Y., Kajii T., et al.: Kabuki make-up (Niikawa-Kuroki) syndrome: a study of 62 patients. Am J Med Genet 1988; 31: 565-589.

[4] Adam M.P., Banka S., Bjornsson H.T., the Kabuki Syndrome Medical Advisory Board, et al.: Kabuki syndrome: international consensus diagnostic criteria J Med Genet. 2019 Feb; 56: 89-95.

[5] Banka S., Veeramachaneni R., Reardon W., et al.: How genetically heterogeneous is Kabuki syndrome?: MLL2 testing in 116 patients, review 
and analyses of mutation and phenotypic spectrum. Eur $\mathrm{J}$ Hum Genet. 2012; 20: 381-388. doi:10.1038/ejhg.2011.220

[6] Lederer D., Grisart B., Digilio M.C., et al.: Deletion of KDM6A, a histone demethylase interacting with MLL2, in three patients with Kabuki syndrome. Am J Hum Genet. 2012; 90: 119-124. doi:10.1016/j. ajhg.2011.11.021

[7] Makrythanasis P., van Bon B.W., Steehouwer M., et al.: MLL2 mutation detection in 86 patients with Kabuki syndrome: a genotype-phenotype study. Clin Genet. 2013 Dec; 84: 539-45.

[8] Yano S., T. Matsuishi, M. Yoshino, et al.: Cerebellar and brainstem 'atrophy' in a patient with Kabuki make-up syndrome. Am. J. Med. Genet., 1997; 71: 486-487
[9] Takano T., Matsuwake K., Yoshioka S., et al.: Congenital polymicrogyria including the perisylvian region in early childhood. Congenit. Anom., 2010; 50: 64-67

[10] Di Gennaro, G., Condoluci, C., Casali et al.: Epilepsy and polymicrogyria in Kabuki make-up (Niikawa-Kuroki) syndrome. Pediatric Neurology, 1999; 21(2), 566-568. doi:10.1016/s0887-8994(99)00030-2

[11] Boisgontier, J., Tacchella, J. M., Lemaître, H. et al.: Anatomical and functional abnormalities on MRI in kabuki syndrome. Neuroimage Clin. 2019;21:101610. doi:10.1016/j.nicl.2018.11.020. 